\title{
The Training Mode for Translation Talents Majoring in Ceramic Art
}

\author{
Zhebo Zhang \\ Department of Foreign Languages and Literatures, College of Technology and Art \\ Jingdezhen Ceramic Institute \\ Jingdezhen, Jiangxi Province, China \\ 160520888@qq.com
}

\begin{abstract}
China has a great influence in the field of ceramics for a long time; also, ceramic-related English is the oldest civilized product of human beings, which makes it different from other ESP. However, as one of the main means of cross-cultural communication, translation practice lags behind in the field of ceramics. Based on the author's teaching and practical experience, this work first analyzed the necessity of reforming the training mode of translation talents majoring in ceramic art, and then put forward some possible ways to establish a new training mode from the perspective of culture concept, course system, project teaching, practice training, teacher's request, and evaluation system.
\end{abstract}

Keywords-Jingdezhen; Ceramic Art; Translation Talents; Training Model; Teaching Reform

\section{INTRODUCTION}

In recent years, Jingdezhen has made tremendous efforts to build ceramic culture projects and to develop ceramic cultural tourism. Under the prosperous situation of ceramic cultural tourism, Jingdezhen local colleges and universities are duty-bound to take on the historical responsibility of cultivating high-quality ceramic translation talents considering the present situation of talents lack in ceramic culture tourism translation. At the same time, Chinese ceramic culture is being deeply integrated into the world cultural heritage; therefore, there will be more demand for talents in ceramic culture translation, which undoubtedly solves the problem of employment difficulties and points out a new employment direction for students majoring English, thus providing more space for their career development.

\section{The Necessity of Reforming the Training Mode of Translation Talents Majoring IN CERAMIC ART}

\section{A. To meet the needs of the cultivation of compound and applied foreign language talents}

With the further deepening of reform and opening up, especially after China's entry into WTO, China has fully participated in the competition in the international scope, and accordingly the market has also posed higher requirements for English talents. The society requires English talents to have solid professional knowledge, high information literacy and the ability to communicate in English in daily life and professional fields. Although many colleges and universities have invested more attention in English major in recent years, there is a lack of innovation in talent training mode, and the inter-disciplinary talents are very rare. The cultivation of "ceramic-based foreign language talents" is in line with the needs of the times and social development, and fully reflects the requirements of compound, applied foreign language personnel training with respect to Jingdezhen's rich local characteristics [1]. At present, the research on translation teaching for non-English majors in China is an active topic, but there are few related achievements regarding ceramic. Therefore, it is of great significance to explore effective teaching models, cultivate their interest in translation, develop practical translation ability and improve translation quality in combination with the actual English proficiency and professional background of non-English majors.

To date, with the increasing development of economic and foreign exchanges in China, the demand for translators in ceramic design, production, trade and tourism is increasing day by day. However, due to the professionalism and complexity of ceramic knowledge, English graduates alone can no longer meet this social demand, so it is urgent to turn the training goal to the majority of ceramic related majors. The profound ceramic professional knowledge, coupled with the English level of many years of study, makes the ceramic related college students competent for the translation of ceramic professional materials through certain translation teaching.

\section{B. To broaden access to employment and provide more employment opportunities}

In the situation that the employment situation of the college students is becoming more and more serious, the personnel training mode needs to be innovated, so that the qualified personnel can be cultivated to meet the needs of the society and the market. Although the English major is a popular profession, the employment prospect seems to be more optimistic; also, the various English talents in the market are relatively saturated, and the employment channel is becoming narrower and narrower. In this case, ceramic translators are likely to become hot topics. As we all know, there are many famous ceramic producing areas like Jingdezhen in China [2-3]. They also urgently need a large number of excellent and qualified high-quality ceramic translation talents in the process of foreign exchange and dissemination of ceramic culture. Under the trend of global economic and cultural integration, China's ceramics must go out of the national gate towards the world, and China's ceramic culture will be more deeply integrated into the world's cultural heritage. Therefore, the demand for ceramic culture translation talents will also be boosting, which 
undoubtedly solves the problem of some students' employment difficulties.

\section{Possible Ways to Establish a NeW Training Mode For Translation TALENTS MAJORING IN CERAMIC ART}

\section{A. Cultivation concept}

In the process of constructing a training mode for professional compound English translation talents, establishing the correct concept is the main spiritual support and intellectual security. On the one hand, teachers in colleges and universities should change their mindsets, pay attention to the development and changes of the translation talent market, and master the needs of translation enterprises for translation talents, so as to clearly recognize that the demand for translation talents in society has fundamentally changed [4]. Under the traditional concept, teachers should focus on cultivating elites of academic research type. However, with the development of society and the needs of the market, practical talents are required by the market, rather than the academic elites in the ivory tower. On the other hand, students should also change their mindsets, grasp the requirements of translation enterprises for translation talents, and strive to improve their employment competitiveness. Only when teachers and students change their concepts at the same time can they better cooperate and complement each other in teaching activities, gradually break the framework of the traditional English translation talents training model, and build a new training model for professional compound English translation talents.

\section{B. Curriculum system}

The construction of the training mode for professional compound English translation talents should rely on a complete curriculum system with substantial contents and a reasonable structure, and at the same time take into account the balance between theory and practice. First, theory and practice should be combined. Although the translation major is more practical more, the theoretical foundation cannot be ignored. The theoretical courses of translation major are the premise and foundation of practical courses. If there is no theoretical guidance, practical translation skills will lack a theoretical basis, leading students to use translation skills mechanically and making students unable to use flexibly in dealing with different translation situations. At the same time, practical courses in the curriculum system should also occupy a considerable proportion, so as to comprehensively cultivate and improve the translation ability of translation talents from all aspects of translation skills. Second, both English and Chinese are equally important. In the current curriculum system of the translation major, the proportion of Chinese courses is relatively small. Nevertheless, translation requires the simultaneous participation of two languages, so the translator should have the ability to master and use both English and Chinese. In addition, language must survive in a certain cultural environment, and qualified translators should master cultural knowledge related to language. Therefore, the complete curriculum system of the translation major should reasonably allocate the proportion of English and Chinese courses to match the construction of the training mode for professional compound English translation talents.

\section{Project teaching}

The development and in-depth translation technology courses introduce language and translation skills into translation teaching, and introduce various techniques and tools used by language workers and translators in professional practice and research to help students adapt to the challenges proposed by the information-based society, which is a feasible way to cultivate talents. In the information-based age, it is necessary for translators to use various translation techniques in their translation work to improve their translation efficiency and quality. While dealing with foreign language ability and translation ability, they should take translation technology courses, and strengthen IT skills, electronic resources, network retrieval and other technologies, so that they can possess the qualities that translators should have. The development of translation technology courses will involve and be committed to, first, helping students build a personal computer environment that can be effectively controlled and develop their skills in using word processing software for complex tasks related to language and translation; second, helping students become familiar with the basics principles of natural language processing, corpus linguistics, translation memory, and translation terminology, and use the expertise and technical tools in these fields to engage in language and translation professions; third, conducting machine translation and computer-assisted translation courses, and introducing the main machine-assisted translation system, so that students can master a mainstream machine-assisted translation tool; fourth, making students familiar with the principles of computer terminology management and mastering terminology extraction, creation and terminology translation techniques; fifth, introducing basic knowledge of project management to students.

Translation project teaching is to introduce the actual translation projects and their working process into the classroom. Through dividing groups in the actual project process, teachers can group students according to their computer technology and language skills, so that they can optimize the member configuration of each group [5]. Each group is roughly divided into project managers, assistants, translators and revisers according to the characteristics of the members. The main process of the project can be referred to Fig. 1. In addition, the curriculum setting of applied translation should be diversified. Under the guidance of the market-oriented translation talent training model, the overall translation curriculum should increase the proportion of non-literary translation courses, and provide courses in science and technology translation, news translation, tourism translation, and legal translation for professional industries with greater demand, so as to highlight the training mode of applied and practical translation talents. 


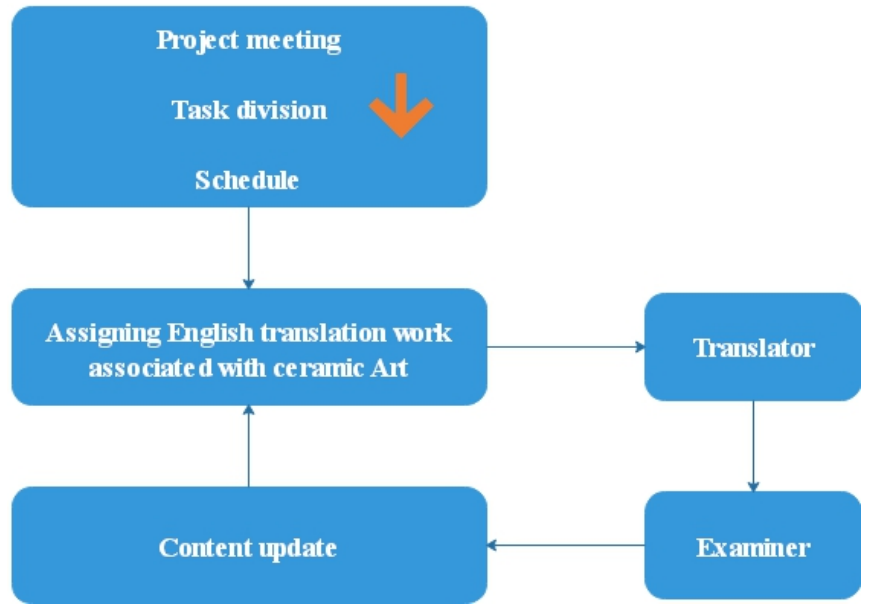

Fig.1. Project teaching model for translation talents majoring in ceramic art

\section{Practical training}

Practice is the standard for testing the ability level of English translation talents. Therefore, practical training is an indispensable way to build the training mode for professional compound English translation talents. In translation training, teachers should minimize the training of literary translation texts and increase the translation training of practical texts in other fields. In the selection of practical translation texts, teachers should pay attention to the needs of social development and fully consider the needs of regional characteristics and regional economic development. Taking Liaoning Province as an example, Liaoning Province is a region where heavy industry is concentrated in northeast China, and most manufacturing enterprises in Liaoning Province are in need of translation talents in economy, trade, science and technology. Therefore, teachers can select translation texts related to the needs of manufacturing enterprises so as to train and improve students' practical ability. In terms of interpreting, teachers should encourage students to pay attention to daily foreign exchange activities and international academic activities, such as the Northeast Asia Forum and business meetings, which are good opportunities for students to learn and exercise [6]. In addition, colleges and universities should actively promote cooperation with enterprises to provide internship opportunities for students. In recent years, the form of school-enterprise cooperation has gradually been recognized by schools and enterprises, and it is a win-win move. Through school-enterprise cooperation, colleges and universities can hire practitioners from the translation industry to provide guidance for students in terms of how to prepare for their employment, and how to become a competent translator in the future. To some extent, this alleviates the problem of students' employment difficulty. Colleges and universities can also communicate with enterprises to establish off-campus practice bases, so that they can provide internship opportunities for students, improve their practical skills and vocational skills and prepare them for employment.

\section{E. Requirements for teaching strength}

Scientific English translation courses have been taught mainly by English teachers who have good Basic English language skills and understand translation theory and translation skills, but they are weak in the field of professional knowledge. If teachers cannot fully understand the content of the scientific translation, it is easy for them to misinterpret, let alone guide students. However, most teachers who understand professional knowledge are not qualified in English pronunciation, oral expression, English translation theories and techniques. It is difficult for students to keep up with the rhythm of teachers and thus lose interest in learning. The science and technology English translation teachers who use translation workshops are not only "mediators, organizers, creator, facilitator, regulators, guide, command, coach" who have basic language skills and understand translation theories and techniques, but are also dual-skilled talents with a certain amount of professional scientific knowledge and rich practical experience in scientific English translation. Without the experience of translators, teachers will not be able to understand the market mechanism and operation of the translation industry, let alone cultivate professional translators. Therefore, it is necessary to actively introduce high-level dual-skilled teachers and actively train young teachers. Ii is also necessary to arrange teachers to visit, practice or research factories and mines in a planned and organized way. Colleges and universities can also hire senior professional translators from enterprises and institutions as part-time teachers to participate in the teaching of professional courses, so as to introduce industry experience into classroom teaching, and let the classroom be filled with realistic translation tasks that are closely related to the society, thus improving the training of translation practice ability for scientific and technological English translation talents.

\section{F. Evolution system}

In traditional English translation courses for science and technology, teachers mainly evaluate students' final performance according to their average scores and daily performance. However, this kind of evaluation is single and mechanical, which is impossible to mobilize students' enthusiasm and participation. In contrast, the translation workshop is a very practical seminar-based teaching method. Instead of summative evaluation, formative evaluation is emphasized in this method. The content of the evaluation can be not only the classroom display or translation, but also the extra-curricular translation practice, such as translation practice of the practice base and translation competition. The evaluation subjects of students' translation work not only include teachers, but also students of the same group or different groups, or even industry experts.

\section{SUMMARY}

Judging from the present situation of Jingdezhen ceramic art translators, the majority of ceramic professionals do not understand or are not proficient in foreign languages, resulting in certain language barriers in the exchange of ceramic knowledge and culture with foreign porcelain enthusiasts and experts. Moreover, students majoring in foreign languages do not know much about ceramic professional knowledge, and ceramic vocabulary is relatively scarce. The lack of learning of ceramic vocabulary and traditional porcelain manufacturing techniques and processes makes it difficult to quickly start the translation work of foreign ceramic communication in a short 
[3] Jie, C.. Reflections on translation talents training caused by the growing economy of Henan province. Journal of Henan Institute of Education (Philosophy and Social Sciences), 2007.

talents training of ceramic art.

\section{REFERENCES}

[1] Limin, L.. Multi-module training mode for application-oriented translation talents. The Science Education Article Collects, 2013.

[2] Du, Y.. Study on Training Mode for Applied Talents of Electronic Commerce: Perspective Based on Cultivating the Ability of Innovation. Proceedings of the 2012 3rd International Conference on E-Business and E-Government - Volume 05

[4] Zhan Yong. Research on the model of business English translator training based on DRM control model. Applied Mechanics and Materials, Vol. 380-384 pp. 2662-2666, 2013

[5] Zhu, Y.. The Study on the Training Mode of Application-Oriented Design Talents in German Industry. IEEE International Conference on Computer-aided Industrial Design \& Conceptual Design. IEEE, 2010

[6] Jian-Xin, Z., \& Hong, C.. A discussion on how to train the bilingual translators in the Colleges of Xinxiang. Journal of Xinjiang Education Institute, 43(3), pp.801-803, 2015. 